\title{
The visibility of environmental rights in the EU legal order: eurolegalism in action?
}

Article

Accepted Version

Hilson, C. (2018) The visibility of environmental rights in the EU legal order: eurolegalism in action? Journal of European Public Policy, 25 (11). pp. 1589-1609. ISSN 1466-4429 doi: https://doi.org/10.1080/13501763.2017.1329335 Available at https://centaur.reading.ac.uk/70293/

It is advisable to refer to the publisher's version if you intend to cite from the work. See Guidance on citing.

To link to this article DOI: http://dx.doi.org/10.1080/13501763.2017.1329335

Publisher: Taylor \& Francis

All outputs in CentAUR are protected by Intellectual Property Rights law, including copyright law. Copyright and IPR is retained by the creators or other copyright holders. Terms and conditions for use of this material are defined in the End User Agreement.

\section{www.reading.ac.uk/centaur}

\section{CentAUR}

Central Archive at the University of Reading

Reading's research outputs online 
The Visibility of Environmental Rights in the EU Legal Order: Eurolegalism in Action?

Chris Hilson

School of Law, University of Reading, UK

\begin{abstract}
The current article responds to a key puzzle and a question. First, why, given the potential for 'rights talk' that has been seen in other countries and other policy areas, have environmental rights in the EU legal order been relatively invisible until recently? And second, with Daniel Kelemen's influential work on Eurolegalism arguing that the EU has become much more reliant on US-style adversarial legalism, including a shift towards rights-based litigation, do EU environmental rights fit the picture Kelemen has painted, or are they an exception? The article explores the visibility of EU environmental rights at EU level and then seeks to explain the possible reasons for visibility/invisibility.
\end{abstract}

KEYWORDS Environmental rights; Eurolegalism; Kelemen; legal opportunity structure; visibility

CONTACT Chris Hilson c.j.hilson@reading.ac.uk

\title{
Introduction
}

Robert Kagan coined the term 'adversarial legalism' to describe the way in which the US policy process routinely involves challenges in the courts, in particular via judicial review (Kagan 1997, 2003). While Kagan was doubtful about whether the seeds of adversarial legalism would ever take firm root in Europe (Kagan 1997), subsequent work by Daniel Kelemen (2011) sought to counter this with empirical data demonstrating that what he termed 'Eurolegalism' was alive and well 
within the EU. Kelemen argues that the EU as a polity has, as a core governance style, been reliant on US-style adversarial legalism to achieve its integration policy objectives. He points in particular to the way in which private citizens have been encouraged to challenge Member State policy breaches in national courts via the legal doctrines of direct effect and supremacy. In securing European integration through law, Kelemen also argues that rights have played an important role. As part of a 'rights revolution', there has, he states, been 'a tendency to expand individual rights and to explicitly frame policies in the language of rights ... across a wide range of policy areas in the EU in recent years' (Kelemen 2011: 51). He is thus claiming that the EU has deliberately employed explicit individual rights framing. Such framing invites citizens to perceive Member State breaches of EU law as breaches of their own entitlements and, because of the logic of legal framing, to challenge these breaches via the courts.

The current article employs environmental policy to test Kelemen's theory. It is important to note that I am not seeking to question Kelemen's argument about EU reliance on Euro-litigation in environmental policy. Existing studies (e.g. Vanhala 2012) demonstrate that challenges in the national courts based on EU law have indeed been a key feature of that policy area. I am instead aiming to test whether Kelemen's specific arguments about rights framing as a core feature of his theory of Eurolegalism are supported by empirical evidence. In other words, does EU environmental policy support the idea of there having been reliance on explicitly rights-framed litigation? That such a reliance might exist is distinctly plausible: with the well-established 'rights talk' and associated legal mobilisation around rights that have been seen in countries like the US, across various policy areas such as civil rights and, more recently, LGBT rights, one might expect EU environmental rights to have taken hold in a similar way in Europe.

In order to address the question of whether EU environmental rights have been visible in this manner or represent instead a puzzling, invisible exception, I examine empirical data on their visibility in litigation at EU level. The data are separated out into different types or categories of EU environmental rights (see below): substantive and procedural rights and fundamental and legislative rights. The data reveals that visibility varies across the particular category of right and across time 
periods. It also shows that explicit rights framing in litigation before the Court of Justice of the European Union (CJEU) has largely been absent across all types until relatively recently. Next, I seek to explain the possible reasons for high or low visibility, drawing in particular on legal opportunity structure. All of this helps us to understand where the rights element of Kelemen's theory works with environmental policy and where it does not. Breaking down the data into different rights categories necessarily involves going into significant legal detail. This detail is needed because there is, otherwise, a risk of non-legal scholars making over-generalised statements about environmental rights in the EU. Different legal environmental rights behave, in visibility terms, in differing ways across time. The cause of visibility or invisibility also varies according to the type of right.

\section{Visibility}

The key research questions which the article seeks to answer are therefore:

(i) To what extent, during recent decades, have different types of EU environmental rights been explicitly visible or invisible in litigation at EU level?

(ii) To the extent that question (i) finds that certain categories of EU environmental rights have been more visible than others, why is that?

Underlying these questions is a puzzle and a theoretical question. The puzzle is why, given the potential for 'rights talk' that has been seen in other countries and other policy areas, have environmental rights in the EU legal order been relatively invisible until recently? True, this may not strike some as a puzzle: there is a view (prevalent, historically, in e.g. German law) that regulatory law aimed at protecting public goods does not give rise to individual rights. However, particularly after the Aarhus Convention (see below), which is centred around the idea of environmental rights, this is an increasingly outdated view. It was also one contested in case law well before Aarhus . While I acknowledge that a perception of this rights unsuitability may form a 
background context for why EU environmental rights have been less visible, my contention is that the puzzle remains. Given that neither the environmental movement nor the CJEU generally appear to share this restrictive view of the place of rights in relation to environmental policy, it is puzzling that there has not been more take up of environmental rights in EU law. The theoretical question then asks whether EU environmental rights fit the picture Kelemen has painted, or if they are an exception.

Both of the initial research questions require prior consideration of what is meant by 'visibility' in the context of the current article. Another way of describing visibility would be the use of rights 'frames' (Pedriana 2006). Rights frames can of course be found in a number of settings (legislation, courts/case law, media, academic outputs), used by a range of actors (academics, practising lawyers, judges, other actors such as NGOs) and it is thus important to determine which and whose frames we are interested in. In terms of 'visibility where?', at EU level I examine the visibility of rights framing within court cases themselves. These are therefore very much 'legal' frames in a narrow sense. As for 'whose frames?', I am interested not only in rights frames used by the CJEU itself in the operative part of its judgments, but also in frames by the parties where these are revealed in those judgments.

\section{EU environmental rights}

It should be said at the outset that the focus of the article is specifically on $E U$ environmental rights: the article is not aiming to study mobilisation and visibility of environmental rights in general. Purely domestic environmental rights frames (e.g. where national constitutions contain an environmental right) and also purely ECHR (European Convention on Human Rights) environmental rights cases with no EU element are not covered.

And, importantly, the focus is on EU environmental rights at EU level - looking at CJEU judgments. Ideally of course, to get a full picture of rights framing in the EU relying on environmental rights claims, one would look not just at CJEU judgments but also those of a number 
of national courts. However, while this would usefully form the basis of a much larger future research project, the current study is largely limited to the EU level courts (although I do consider some UK national court cases in passing, these cases are not counted in the key data and are used more to illustrate the potential power of rights framing in environmental cases). This CJEU focus can be justified in two respects. First, many of the cases involve preliminary references from various national courts across the EU, and hence the article inevitably reveals something about EU environmental rights framing in national courts. Had national courts been employing rights framing, one would expect to see some evidence of that in the references handled by the CJEU. Second, and perhaps more significantly, the CJEU sets the context for rights framing in EU environmental law. In other words, one would in any event be unlikely to see rights framing used in national courts without the CJEU having itself used that language.

EU environmental rights can be divided into legislative and fundamental, and both of these may be substantive or procedural in nature. Legislative rights are those found principally in EU directives. Some, though (pace Kelemen) relatively few, environmental directives employ the express language of rights in their provisions. For the majority however, rights can be seen as correlatives in a Hohfeldian sense to the duties or obligations owed to citizens by Member States under those directives (Hilson and Downes 1999; Hohfeld 1919). The CJEU has over the years sought to constitutionalise the EU treaties, stressing that many of the obligations owed by Member States in the treaties and legislation such as directives create rights for citizens enforceable in their national courts. This is the foundation of the well-known EU law doctrine of 'direct effect'. Within legislative rights, substantive rights notably include those which entitle citizens to a particular substantive level of environmental quality, whereas procedural rights provide for a right to a particular procedure. An example of the former would be a right to clean drinking water in compliance with the substantive quality standards set out in the Drinking Water Directive 98/83/EC. An example of the latter is the right of access to environmental information enjoyed under Directive 2003/4/EC on Public Access to Environmental Information. 
Fundamental EU environmental rights include those in the EU Charter of Fundamental Rights and also those found in, or derived from, the ECHR (in the latter case, the Court of Justice will have absorbed them into its own in-house doctrine of fundamental rights as part of the 'general principles of law'). As de Sadeleer observes of ECHR-related rights: 'although EU law does not specify a selfexecuting right to environmental protection, such a right emerges in the wake of fundamental rights enshrined by the ECHR' (de Sadeleer [2014]: 125). These ECHR rights include both substantive rights under, for example Article 8 (home and family life) and Article 2 (right to life) and procedural rights under Article 6 (right to a fair trial). The ECHR case law on environmental rights has grown significantly, including cases ranging from airport noise (Hatton), ${ }^{1}$ through factory pollution (Lopez Ostra $)^{2}$ to failures to warn about risk (Guerra) ${ }^{3}$ In terms of the EU Charter of Fundamental Rights, the environmental Article, 37, states:

A high level of environmental protection and the improvement of the quality of the environment must be integrated into the policies of the Union and ensured in accordance with the principle of sustainable development.

While Article 37 may be legally justiciable in limited circumstances (Bogojević 2017; de Sadeleer 2014), this will be as a principle rather than a right, with the Charter drawing a thin line between the two (de Sadeleer 2014). That is not to say that Charter environmental rights do not exist. They do, but it is just that, like the development of the ECHR's case law on the environment, the environmental rights in the Charter (which broadly mirror the relevant ECHR rights) are 'derived' rights based on other Charter rights such as the right to life in Article 2, the right to private and family life in Article 7 and the right to property in Article 17. Again, like the ECHR above, the Charter-based fundamental rights may be substantive or procedural in nature (with the Article 47 right to an effective remedy and fair trial an obvious example of the latter and the right to property an example of the former).

\section{Research design}


Answering the initial research question about the extent of visibility involved collecting quantitative data on EU environmental rights frames at EU level. For this I used the CJEU's Curia database to search for relevant case law principally within its 'Environment' subject matter, using various terms including rights, Aarhus, Charter, fundamental, ECHR, general principles, as well as seminal ECHR rights cases such as Lopez Ostra and Guerra and EU cases on rights identified from EU environmental law books and journal articles with an environmental rights focus.

In methodological terms, deciding which cases counted as 'environmental' and thus which frames would be counted was relatively straightforward for legislative rights: it was a matter of whether the legislation at issue in the case was environmental or not within the CJEU's case law database classification system. This means for example, that while cases on access to environmental information were included (because this comes within an environmental directive), cases relying on access to information held by the EU institutions were not (because, although many such cases are brought by environmental NGOs such as ClientEarth, they rely on generalist legislation on access to information rather than specifically environmental legislation, and the former does not confer an environmental right as such). With fundamental rights in contrast, because such rights are almost exclusively 'derived' rights, establishing what cases to include was more difficult. In most cases the legal challenge will relate to an item of environmental legislation which, it is claimed, breaches one of the parties' fundamental rights. However, the data also includes cases such as Schmidberger ${ }^{4}$ involving environmental protest, where the argument is that the rights to free expression and assembly (to protest on environmental grounds about road transport) should be allowed to justify an interruption of the Treaty-based free movement of goods (blocked by the protest).

To avoid unnecessary overlap/double counting, the focus was on CJEU judgments and not Advocate General Opinions. For similar overlap reasons, where a case had been appealed, only the framing in the appeal case was analysed. Finally, as mentioned earlier, within CJEU judgments, the legal framing examined was mostly that of the Court itself but, where included, the frames put forward by the parties were also considered. 
In terms of what types of statements in court rulings or litigant submissions were counted as instances of environmental rights framing, not only did the word 'right/s'/have to appear, but this also had to be in the context of an identifiable environmental element and not just referenced in passing or incidentally. An example of a rights framing case that was included is the Greenpeace $v$ Commission judicial review of restrictive CJEU standing rules. ${ }^{5}$ Greenpeace alleged that their inability to challenge the Commission's decision to fund two power stations on the Canary Islands without a prior environmental impact assessment (EIA) deprived them of their rights under the EIA Directive 85/337. In response, the Court stated:

As regards the appellants' argument that application of the Court's case-law would mean that... the rights which they derive from Directive 85/337 would have no effective judicial protection at all, it must be noted that ... Greenpeace brought proceedings before the national courts challenging the administrative authorisations ... concerning the construction of those power stations. Although the subject-matter of those proceedings and of the action brought before the Court of First Instance is different, both actions are based on the same rights afforded to individuals by Directive 85/337, so that in the circumstances of the present case those rights are fully protected by the national courts which may, if need be, refer a question to this Court for a preliminary ruling. ${ }^{6}$

\section{Time periods}

The research involved a longitudinal study across three time periods:

i) $\quad 1990-2000$ (the 1990s being a key period for the development of the legal doctrines of direct effect and state liability, and also for the growth of ECHR environmental jurisprudence such as Lopez Ostra and Guerra); 
ii) 2001-2008 (from the entry into force of the Aarhus Convention in 2001, which introduced a range of procedural environmental rights that were then gradually incorporated into EU legislation, to the entry into force of the Lisbon Treaty in 2009);

iii) $\quad 2009-2015$ (2009 marking the entry into force of the Lisbon Treaty, at which point the EU Charter of Fundamental Rights took on binding force).

The three periods thus allow for consideration of potential changes in visibility brought about by direct effect, state liability and ECHR environmental case law, by Aarhus, and by the Charter of Fundamental rights.

\section{Results on visibility}

Table 1. EU level visibility.

\begin{tabular}{|c|c|c|c|}
\hline $\begin{array}{l}\text { Legislative } \\
\text { environmental rights } \\
\text { cases: }\end{array}$ & $1990-2000$ & $2001-2008$ & $2009-2015$ \\
\hline \multicolumn{4}{|l|}{ Incorrect transposition } \\
\hline - procedural & 1 & 2 & 2 \\
\hline - substantive & 3 & 0 & 0 \\
\hline $\begin{array}{l}\text { Direct effect (all } \\
\text { procedural) }\end{array}$ & 2 & 1 & 4 \\
\hline $\begin{array}{l}\text { State liability (all } \\
\text { procedural) }\end{array}$ & 0 & 0 & 1 \\
\hline $\begin{array}{l}\text { Infringement } \\
\text { proceedings (all } \\
\text { procedural) }\end{array}$ & 1 & 1 & 0 \\
\hline \multicolumn{4}{|l|}{$\begin{array}{l}\text { Standing/judicial } \\
\text { review }\end{array}$} \\
\hline - procedural & 1 & 0 & 0 \\
\hline - substantive & 0 & 0 & 1 \\
\hline $\begin{array}{l}\text { Access to } \\
\text { environmental } \\
\text { information (all } \\
\text { procedural) } \\
\end{array}$ & 1 & 2 & 8 \\
\hline Aarhus (all procedural) & 0 & 0 & 13 \\
\hline \multicolumn{4}{|l|}{$\begin{array}{l}\text { Fundamental } \\
\text { environmental rights } \\
\text { cases: }\end{array}$} \\
\hline $\begin{array}{l}\text { No. of cases with } \\
\text { industry relying on } \\
\text { frame }\end{array}$ & 1 & 1 & 11 \\
\hline
\end{tabular}




\begin{tabular}{|l|l|l|l|}
\hline $\begin{array}{l}\text { No. of cases with pro- } \\
\text { environmental actor } \\
\text { relying on frame }\end{array}$ & 0 & 0 & 1 \\
\hline $\begin{array}{l}\text { No. of cases with } \\
\text { Member State relying } \\
\text { on frame }\end{array}$ & 0 & 2 & 3 \\
\hline $\begin{array}{l}\text { No. of substantive } \\
\text { frames }\end{array}$ & 1 & 1 & 10 \\
\hline $\begin{array}{l}\text { No. of procedural } \\
\text { frames }\end{array}$ & 0 & 2 & 7 \\
\hline No. of Charter frames & 0 & 0 & 9 \\
\hline $\begin{array}{l}\text { No. of fundamental } \\
\text { rights as general } \\
\text { principles of law } \\
\text { frames }\end{array}$ & 1 & 2 & 9 \\
\hline No. of ECHR frames & 0 & 1 & 5 \\
\hline $\begin{array}{l}\text { Total number of } \\
\text { different rights frames }\end{array}$ & 10 & 9 & 52 \\
\hline $\begin{array}{l}\text { Total number of } \\
\text { legislative and } \\
\text { fundamental rights } \\
\text { cases (discounting } \\
\text { overlaps) }\end{array}$ & 8 & 8 & 32 \\
\hline
\end{tabular}

Table 1 shows data on EU-level cases involving environmental rights frames during the three relevant time periods. The cases have been divided up, in the far left column, into two overarching categories (in bold): legislative environmental rights cases and fundamental environmental rights cases. There is a degree of overlap in terms of counting between some of the types of rights: for example, where a case involves both incorrect transposition rights framing and access to environmental information rights frames, it will be counted within both (i.e. double counted). I have not, however, double counted incorrect transposition cases and infringement procedure cases although the former are all also examples of the latter. This is because, unlike the other categories infringement cases are not an identifiable type of rights framing in themselves; they are, rather, a procedural form (Commission v Member State) in which another of the listed rights frames has arisen before the Court. Other common overlaps between rights frames that have been double counted include Aarhus rights frames and access to environmental information rights frames, and also Charter rights frames and ECHR rights frames. In other words, what is being counted here is whether a particular type of frame appeared in a case, and many cases will have more than one 
frame type within them. I have not, however, counted the number of times the same frame is mentioned in a case: thus, for example, if a Charter right is mentioned seven times, it is still only counted as one Charter framing. The benefit of this approach is that it enables one to capture the emerging pattern of framing over time within different types of rights cases. The bottom of the Table includes totals for both the number of types of rights frames during each period ${ }^{7}$ and, underneath that, for the total number of cases that made use of at least one type of environmental rights frame. The latter enables one to assess whether there were more cases involving rights framing, as opposed to there being a similar number of cases invoking such framing, but with more separate frames within each case.

Some comment is also needed on the various sub-categories in the left hand column that sit underneath the two overarching categories. A number of these are relatively straightforward and require little in the way of explanation: an Aarhus case for example, will have involved a case with an Aarhus-based rights frame from the EU package of Aarhus legislation; a Charter case will have involved rights framing based on a right from the EU Charter of Fundamental Rights; a fundamental rights case will have involved framing based on the CJEU's own general principles of law (without reference to the Charter or ECHR); and an ECHR case will have seen an ECHR-based rights frame (as opposed to the Charter or 'in-house' fundamental rights framing). Bearing in mind the observation in the previous paragraph, cases can also of course have more than one of these frames within them.

Other categories require a little more background context. The 'incorrect transposition' cases involve Member State failure to transpose directives into national law in a form which provides sufficient legal certainty to enable individuals to enforce their rights under them. This of course begs the question of which directives do in fact confer rights, thereby requiring proper transposition. The Court's case law from the 1990s suggested that environmental directives designed to protect human health conferred such rights and a number of the cases involved substantive environmental quality directives (e.g. on air quality) which were clearly aimed at protecting human health. ${ }^{8}$ Rights framing by the Court is thus evident in these cases, although there was also a case in the first (1990- 
2000) period involving a procedural directive where no association with health was made and yet a rights frame was similarly used. ${ }^{9}$

With 'direct effect', there was a significant academic debate within EU law in the late 1990s to early 2000s on whether a right was a condition for the direct effect of directives or the result of it (e.g. Hilson and Downes 1999; Prechal and Hancher 2002). With the latter, a provision in a directive would be said to confer a right which an individual could enforce in their national courts if the conditions for direct effect of sufficient precision and unconditionality were satisfied. With the former, the enjoyment of a right would be another condition to be added to these two. The argument has long since been won by the result camp. Two of the cases (one from the first period and one from the last) are clearly of the result kind. The final case that arose in the direct effect category (in the last period) was the appeal in Stichting Natuur en Milieu and PAN Europe, ${ }^{10}$ where the applicants attempted to invoke the direct effect of a core Aarhus Convention right on access to justice (with this right forming the relevant environmental rights frame).

Unlike direct effect, where rights are not a condition for the operation of the legal doctrine which enables individuals to enforce EU law in their national courts, 'state liability' under Francovich/Brasserie du Pecheur ${ }^{11}$ does contain an explicit rights requirement before individuals can sue for damages as a legal remedy in national courts. Given this, it is no surprise to find rights framing by the Court in this instance, although it is perhaps surprising that there is only one environmental state liability case at EU level - Leth ${ }^{12}$ - and that it was heard only in the most recent period.

The other two non-obvious categories are 'infringement cases' brought by the Commission against Member States, and cases on 'judicial review' of the EU institutions, including who has standing to challenge the legality of EU measures before the CJEU. One of the infringement cases involved Germany claiming that the relevant provision of the EIA Directive did not confer rights on individuals (supposedly making the Commission's action against it inadmissible) ${ }^{13}$ in the other, the Commission was arguing that the payment of fees had an undue effect on rights to public 
participation under the EIA Directive. ${ }^{14}$ The standing case within the judicial review category was quoted earlier and saw Greenpeace arguing that restrictive standing rules meant that they were unable to enforce their (procedural) rights under the EIA Directive. The other judicial review case involving a legislative ${ }^{15}$ rights frame was Poland $v$ Commission,${ }^{16}$ where Poland argued, in the context of the EU emissions trading system, for reliance on the substantive Article 194(2) TFEU right of a Member State to determine its energy choices. Although many of the fundamental rights cases also involve judicial review, they do not belong here in the Table because they are concerned with fundamental rather than legislative rights.

\section{Interpreting the results}

What is immediately apparent is how relatively invisible any environmental rights framing was during the two early periods. It is only in the most recent, post-2009 period that such rights framing has become much more visible. It is also striking that substantive legislative environmental rights claims are so invisible (with the exception of a brief flurry of non-transposition cases in the earliest period) and that this has continued to the present day. Substantive fundamental rights frames were likewise relatively invisible in the earlier two periods but have risen significantly in visibility since 2009. Procedural rights - both legislative and fundamental - have also seen a significant rise in visibility in recent years.

The fact that direct effect-based substantive legislative rights cases have been thin on the ground is somewhat puzzling. In principle, these should look attractive to the environmental movement because of the potential normative power of rights framing in salient cases directly involving environmental quality. Two cases brought in the UK national courts, while not part of the data (because they are not CJEU cases), help to illustrate this. One might be characterised as a missed opportunity for the movement to flag substantive environmental rights. In the other, the opportunity was firmly seized. The first is the 1994 judicial review by Friends of the Earth (FoE), which 
challenged enforcement 'undertakings' in relation to drinking water quality offered by water companies and accepted by the Secretary of State. ${ }^{17}$ In court, FoE's counsel argued that:

the Community citizen has had since 1985 a right under Community law to wholesome water; such a right must be enforceable. Under the Act the only method of enforcement at the hands of an individual is that provided by section 22 and this only arises once an enforcement order has been made. Therefore, by not making an enforcement order the Secretary of State deprives the individual of the possibility of enforcing his right under Community law. The essence of this submission is that by accepting an undertaking the Secretary of State is depriving the citizen of a right he enjoys under Community law and, therefore, the acceptance of the undertaking by the Secretary of State is illegal. ${ }^{18}$

Counsel thus framed the UK's obligations to meet the EU Drinking Water Directive's quality standards as giving rise to a substantive 'right under Community law to wholesome water'. However - perhaps surprisingly given the high profile nature of the case and the rights framing opportunity it presented - this technical rights framing in court was not really matched with rights framing by FoE in its campaigning outside court. A letter to The Times from water campaigner Liana Stupples (1993) does not mention rights to clean drinking water at all. The FoE (1994) press release does mention such a right, but only once on the second page. The foregrounded frame is, instead, 'polluter pays' (which receives one implicit and four explicit references).

A more recent example of a UK national court environmental case involving a direct effect-type substantive legislative rights frame, is the ClientEarth judicial review of the UK Government for breaching EU air quality standards. ${ }^{19}$ The case is the mirror image of $F o E$ : there is no mention of rights in the legal judgments themselves - it comes, rather, heavily promoted in associated publicity. Thus ClientEarth's (2014) press release starts with the statement that 'We believe that everyone has the right to breathe clean air. That's why we brought our successful air pollution case against the UK to the Supreme Court'. CEO James Thornton is then quoted as saying 'We have the right to breathe clean air and the government has a legal duty to protect us from air pollution.' In an 
earlier press release commenting on the Supreme Court's call for an expedited hearing by the CJEU, ClientEarth lawyer Alan Andrews commented: 'We can't afford to wait for this case to grind its way through the courts. The longer these limits are broken, the more people will die. We need a landmark ruling on our right to clean air in 2013 ' before going on to state 'We have a right to breathe clean air - this is another big step forward in making that right a reality' (ClientEarth 2013).

What the two UK national court cases illustrate is the potential power for the environmental movement of a substantive legislative rights frame in cases involving substantive environmental quality directives. The surprise perhaps is that in $F o E$, its power does not seem to have been fully recognised. In contrast, in the ClientEarth case it was used extensively. So, given this potential, as we can see from Table 1, why have there been so few examples of substantive legislative rights framing?

Legal opportunity structure (LOS) is potentially a key variable that can help to explain both the invisibility of this particular type of right and the visibility/invisibility of other types considered below. LOS consists of structural rules on access to the courts (standing and costs), 'legal stock' (available law in the sense of precedents, rules or legal arguments on which to build a case), and judicial receptivity (Andersen 2005; Hilson 2002; Vanhala 2011). We will see below that, for EU environmental rights to be visible in the sense of having been used frequently in the courts, legal stock plays a particularly important role. If the available law does not require you to use the language of rights, then visibility of rights within the case law will be low; if, in contrast, new laws come in that are expressly centred on rights, then rights visibility within cases will be high. However, alongside LOS's predominantly top-down, structural approach, many now also acknowledge a place for more bottom-up perspectives, taking into account varying perceptions of LOS and the role of actor agency in both responding to and potentially shaping LOS (Vanhala 2011, 2012).

With direct effect, an obvious explanation for the low visibility of rights frames in the case law is a lack of juridical need. At the time of the $1994 F o E$ case for example, it was still uncertain whether 
rights were a condition of direct effect or the result, and that may be one reason why we see it being pleaded as part of the legal argument in the case itself - in case the national court followed a condition-based approach. By the time of the 2014 ClientEarth case, the results-based approach had long been settled which is why we don't see the rights frame in the case itself but just in the publicity surrounding it: there was no juridical need and hence no place for it in the former. In fact, it may go further than just legally not needing to use it, to there having been a real incentive not to do so. That is because in the 1990 s there was a read-across from the 'incorrect transposition' to the 'direct effect' case law, such that some commentators argued that directives would only be directly effective where they conferred rights, and that rights would only be enjoyed under directives which were aimed at protecting public health (Hilson 1997). Hence the danger in running a rights frame in environmental cases was that it might end up effectively endorsing a view that only health-based directives would be capable of direct effect (and that, for example nature conservation directives like the Birds or Habitats Directives would not be). In other words, running a rights frame was a double-edged sword: it offered the power and currency that was evident in extra-judicial publicity in ClientEarth; however, it also ran the risk of legitimising a rather restrictive scope for the direct effect of environmental directives. The above can be analysed in legal stock terms within LOS. If there is no need and thus no place to run a rights frame within existing precedents - and indeed there are some risks in doing so - then the legal stock is not favourable to rights visibility.

There is another possible LOS-based explanation for low visibility in direct effect cases besides lack of juridical need. And that is the so-called 'proceduralisation' of EU environmental law and policy (Scott 2000; Lee 2005), which reached its apogee with Aarhus but in fact began in the decade before that. This proceduralisation has involved a shift in the legal stock, away from directives with clear, direct substantive environmental quality standards in the 1970s and 1980s (e.g. the Drinking Water, Bathing Water and Air Quality Directives) to directives with more procedural forms of governance. Where newer directives do contain substantive quality standards, these have appeared more nuanced in form, as in e.g. the Water Framework Directive 2000/60/EC (Howarth 2009, though cf. now Case C- 461/13 Bund für Umwelt und Naturschutz Deutschland ${ }^{20}$ ). 
As substantive quality directives have become less common, with procedurally-based ones increasingly finding favour, ${ }^{21}$ it is not surprising that substantive rights framing has been less evident.

Of course, as adverted to above, structural LOS approaches are unlikely to offer the only explanation for low visibility. Actor agency in bringing cases is another potential factor. If environmental NGOs for example are not bringing judicial review cases challenging government action on substantive environmental quality directives (like Bathing Water, Air Quality, Drinking Water) and see other areas of policy as more salient for their campaigning, then substantive legislative rights framing can also be expected to be low for that reason. But even if they do choose a substantive quality directive on which to base a campaign, they must also have a degree of rights consciousness (Ewick and Silbey 1998) in order to 'see' that the relevant directive's obligations can usefully be framed in rights terms. Any lingering Germanic scepticism, mentioned earlier, of individual rights arising from regulation aimed at public goods, would of course stand in the way of this. In relation to extrajudicial framing, while ClientEarth above clearly saw the directive in rights terms, it seems that FoE did not (or did so only partially). In interview it appears that a reason for ClientEarth seeing this was down to its legal mobilisation support structure (Epp 1998) - in this case, the presence of lawyers within the organisation who were familiar with the rights framing from the earlier 1990s case law.

Turning from 'direct effect' to the 'incorrect transposition' category, the reason here for the dropoff in visibility from the early examples of substantive legislative rights frames that can be seen in the Table is not the absence of juridical need. It is true that the Court subsequently pointed to a similar need for correct transposition in the case of non-health-based directives like the Birds Directive where, instead of health and rights framing, it speaks of a 'common heritage' entrusted to Member States. ${ }^{22}$ However, in a number of procedural directive cases in recent years, it has continued to use a rights frame, except without making any link with health. In other words, rights framing has not disappeared from the way in which the CJEU approaches the legal stock. More likely than a lack of juridical need then is that, especially given the proceduralisation of EU 
environmental law, there are fewer substantive directives that have been introduced in the two most recent periods which Member States have incorrectly transposed. In a LOS sense, the legal stock of relevant directives has thus diminished.

Of the remaining legislative rights categories in Table 1, state liability is also surprising for its very thin numbers, particularly given that, unlike direct effect, rights are an explicit condition of the legal stock under Francovich/Brasserie du Pecheur. It is difficult to assess why there has been only one case at EU level - Leth - and a procedural rights one based on the EIA Directive at that. If one looks at the UK - where there is similarly only one environmental state liability case (Bowden v South West Water, ${ }^{23}$ which involved a substantive legislative right under the Shellfish Waters Directive 79/923/EEC) - then the EU level low visibility does not appear out of the ordinary. It may simply be that difficulty, in environmental cases, of establishing the other conditions of state liability besides rights (sufficiently serious breach and causation) has made state liability claims, and hence rights framing within this category, thin on the ground.

Why then have we seen a rise in procedural rights? With legislative procedural rights, one obvious answer appears to be the EU's 'Aarhus package' of legislation, introduced in the mid-2000s to implement the international law Aarhus Convention. ${ }^{24}$ Aarhus consists of three 'pillars' - access to justice, information, and public participation - and all three are couched in rights terms within the Convention and relevant implementing EU legislation. Aarhus has made EU legislative procedural environmental rights more visible in part no doubt because the legislation uses the explicit language of rights and hence a case based on it will naturally also use rights framing. This is not so much a juridical need (cf. the 'lack of juridical need' in the case of direct effect above) as a juridical inevitability, which can, again, be linked with the idea of LOS. Procedural legislative rights framing has increased in visibility in part because the implementation of Aarhus created a favourable legal stock for rights claiming.

With fundamental rights, matters are somewhat more complicated. Clearly, the fact of the Lisbon Treaty granting the Charter of Fundamental Rights binding force appears to have led to a significant 
rise in fundamental rights cases generally - whether specifically framed in terms of Charter rights, or using ECHR or in-house 'fundamental rights as general principles' frames. Again, as with Aarhus and legislative rights, one might link this with LOS: the Charter offered an improved LOS through a now binding legal stock while at the same time raising the profile of rights by showcasing them in a new, widely discussed, form. These Lisbon changes made the legal opportunity more apparent, and could thereby be said to have invited more litigants to bring cases based on rights. The legitimacy given to rights by Lisbon may also have emboldened judges to use rights frames more freely than they did in the past. Both of these might help to explain the increase in rights frames in the final period.

And unlike with legislative rights, the post-2009 period has seen not just a growth in the visibility of procedural fundamental rights frames but also in substantive frames. However, a look at the environmental fundamental rights cases that have been brought reveals that the majority of them has involved industry arguing that an EU environmental measure is too strong and negatively impacts on their rights - typically the substantive right to property and/or procedural rights such as rights of the defence and the right to a fair hearing. Where industry is relying on a substantive fundamental rights frame, it is therefore doing so in an anti-environmental manner. A number of substantive fundamental rights frames have also been raised in litigation involving Member States and some of these are pro-environmental. In Commission v Austria ${ }^{25}$ for example, Austria pleaded the right to private and family life in Article 7 of the Charter and Article 8 of the ECHR - a substantive right to be free from harmful pollution - as a justification for its infringement of free movement of goods arising from a sectoral traffic prohibition. However, the only case involving fundamental rights framing by an environmental actor $-R(E d w a r d s) v$ Environment Agency - involved a procedural rather than a substantive rights frame. ${ }^{26}$ Why then have there been no environmental actor examples relying on substantive fundamental rights frames? It is after all, puzzling that there have been no pro-environmental substantive fundamental rights challenges brought by environmental NGOs, arguing that EU environmental action is too weak. That we have seen no such challenges is not just because of poor LOS in terms of lack of standing before the CJEU - in other words an inability for 
an applicant to gain access because of the restrictive Plaumann ${ }^{27}$ approach. It is, in any event, possible to make such challenges in the national courts and not face this standing hurdle at EU level - Standley ${ }^{28}$ is just such a case (albeit with an industry challenger), which involved farmers challenging the Nitrates Directive 91/676/EEC in the UK national courts. One likely explanation is that of redundancy: there will often be no need to bring a case based on a breach of EU substantive fundamental rights, because other legal opportunities are much more likely to be used instead. In a severe pollution incident case like Lopez Ostra for example, a victim is much more likely to proceed via national courts and the European Court of Human Rights without needing to rely on EU law. Another potential reason involves poor legal stock. In essence, ECHR case law does not come to the aid of those arguing that future risks pose a threat: for ECHR rights to be engaged, risk must be imminent (de Sadeleer 2014; Hilson 2009). And needless to say that in most cases where an environmental NGO might be challenging weak EU environmental action on rights grounds, it will be on the basis that the EU is not doing enough to address a future or non-imminent risk. Standley, in contrast, was an industry challenger - and they will almost invariably (though typically unsuccessfully, as in Standley) be arguing in national courts that what they regard as overly strong national environmental regulation is based on parent EU legislation which is unlawful because it breaches their fundamental right to property.

\section{Kelemen's theory revisited}

As outlined at the start, Kelemen's theory of Eurolegalism argues not just that the EU has strategically relied on litigation as a key part of its governance, but also that explicitly framed rights have been central to this strategy. He states that the EU has deliberately employed the language of rights across numerous EU policy areas. This proliferation of rights framing has, he claims, been instrumental in the cause of European integration: creating rights at federal level is capable of sparking 'rights revolutions in which enforcement litigation extends the impact of federal power and the power of the center vis-à-vis the states' (Kelemen 2011: 51). By marshalling the power of 
rights-wielding, private citizen enforcers in national courts, the EU as principal has been able to keep the discretion of EU Member State agents in check. However, Kelemen inevitably paints with a broad brush and the policy areas used as empirical support for Eurolegalism in his book (e.g. EU disability rights) do not provide us with a complete picture. While Kelemen examined environmental policy in an earlier article (Kelemen 2006), this does not engage with environmental rights in any legal depth. Hence, having now examined EU environmental rights in detail, we are in a position to assess whether this area helps to confirm or deny Kelemen's theory. The data from the current study on EU environmental rights reveals a more complex picture than Kelemen's theory might suggest. While direct effect has undoubtedly played an important part in the enforcement of EU environmental law, the specific role of rights framing as part of this is much less apparent. So European litigation, yes, and even litigation involving implicit environmental rights, but European litigation based on explicit rights framing, not really. Next, the EU legislator has, over the past two decades, increasingly turned away from the creation of directives which confer substantive rights, to more procedurally oriented legislation. This process of proceduralisation has of course been amplified in recent years by the introduction of the Aarhus package. Thus, while Eurolegalism undoubtedly exists in EU environmental policy, it is in large part based on procedural rights. Although a reliance on procedural rights remains Eurolegalism - indeed both Kelemen and Kagan emphasise the centrality of such rights to legalism - procedural rights arguably provide a less powerful type of legalism. They offer less purchase than more salient substantive rights which enable claims to specific levels of environmental quality. Finally, if one looks at fundamental rights, then while that category of right has seen substantive framing in recent years, the picture is largely one of policy questioning (by industry) rather than policy reinforcing litigation brought by allies in the environmental movement with interests wedded to those of the federal EU institutions. Industry reliance on, for example, property rights frames, does not aid the cause of European integration as posited by Eurolegalism - it is typically trying to reverse it.

\section{Conclusion}


We have seen that different types of EU environmental rights have enjoyed varying levels of explicit visibility in EU Court judgments. All EU environmental rights were relatively invisible during the initial two periods 1990-2000 and 2001-2008, with visibility increasing markedly during the final 2009-2015 period after the Aarhus package reforms had bedded in and after the Charter was made binding by the Lisbon Treaty. However, while fundamental rights cases saw significant numbers of both substantive and procedural rights frames, legislative rights cases saw an increase only in procedural rights frames: the potentially more salient substantive legislative rights have not had much of a look in. I then sought to explain the possible reasons for the variations in visibility revealed by the data, with LOS playing an important role here. For some types of environmental rights such as legislative, direct effect-based rights, a lack of juridical need within the legal stock seemed to possess some potential explanatory force, as did actor rights consciousness, agency and access to legal support structures with rights knowledge in the area. For other case categories which had seen substantive rights framing in the past - notably the incorrect transposition cases - recent low visibility seemed to be more a matter of a drop-off in substantive environmental directives due to the general proceduralisation of the legal stock of EU environmental law that had been taking place outwith the Aarhus process. There are simply fewer directives like the Bathing or Drinking Water Directives coming onto the statute book these days. As for fundamental rights, the legal opportunity presented by the newly binding Charter and the positive signals this sent to litigants and judges would appear to explain the sudden increase in visibility post 2009. Although both substantive and procedural fundamental rights were seen during this period, the former consisted principally of anti-environmental frames such as the right to property rather than pro-environmental ones. I suggested that this is likely to be down to redundancy (with other legal opportunities more likely to be used) or poor legal stock facing the environmental movement (the problem of establishing imminent risk).

In terms of Eurolegalism, I have argued that the picture with environmental law and policy is more complicated than Kelemen's theory suggests. We have undoubtedly seen Eurolegalism in environmental policy: EU-based litigation has been important and much of this has involved 
implicit environmental rights. However, Kelemen's theory of Eurolegalism argues that explicit rights framing is important. And, for reasons outlined above, we have found that litigation relying on explicit rights frames has not been prominent across all periods and types of rights. Back in the late 1990s, I expected to see many more cases like the recent ClientEarth UK air quality one, with EU rights framing at the core of environmental movement strategy. But the truth is that that vision never really materialised. Instead, a Eurolegalism relying on rights frames has been a relative latecomer to the environment as a policy area. And the rights that have been evident are - in the case of legislative rights - procedural rather than substantive in nature and in that respect, offer a somewhat less powerful Eurolegalism: procedural rights are important and have been involved in some key victories for the environmental movement in recent years; however they lack the salience and force of their substantive cousins. And although fundamental rights have seen substantive as well as procedural rights framing, the mainly anti-environmental nature of the former, employed by industry, means that any integration enhancing quality is very much absent.

\section{Notes}

${ }^{1}$ (2003) 37 EHRR 28.

2 (1995) 20 EHRR 277.

3 (1998) 26 EHRR 357.

${ }^{4}$ Case C-112/00 [2003] ECR I-5659.

${ }^{5}$ ClientEarth and Housieaux are examples of cases not included. ClientEarth contains one mention of rights which is merely incidental to the case and is related to a general Treaty provision (art 4 TEU) rather than an environmental one: 'As regards Article 4 TEU ... according to settled case-law, under the principle of sincere cooperation laid down in paragraph 3 of that article, it is for the Member States to ensure judicial protection of an individual's rights under EU law' (C-404/13 (2014) [52]). No discussion of whether such rights existed in relation to air quality followed. Housieaux (Case C-186/04 [2005] ECR I-3299) involved the Directive on access to information on the environment, but contains no references to rights at all.

${ }^{6}$ Case C-321/95 P [1998] ECR I-1651, [32]-[33].

${ }^{7}$ This is not a simple sum of all rows because the Table also contains data on e.g. the type of litigant and this total does not count these; nor does it double count procedural and substantive fundamental rights frames on top of ECHR, Charter etc types.

${ }^{8}$ Case C-58/89 Commission v Germany [1991] I-4983; Case C-59/89 Commission v Germany [1991] ECR I-2607; Case C-298/95 Commission v Germany [1996] ECR I-6747.

${ }^{9}$ Case C-217/97 Commission v Germany [1999] ECR I-5087.

${ }^{10}$ Cases C-404/12 P and C-405/12 P (2015)

${ }^{11}$ Case C-6/90 Francovich [1991] ECR I-5357; Cases C-46/93 and C-48/93 Brasserie du Pêcheur and Factortame [1996] ECR I-1029.

${ }^{12}$ Case C- 420/11 (2013).

${ }^{13}$ Case C-431/92 Commission v Germany [1995] ECR I-2189.

${ }^{14}$ Case C-216/05 Commission v Ireland [2006] ECR I-10787.

${ }^{15}$ In fact a (non-fundamental) Treaty-based right here rather than a legislative one per se. 
${ }^{16}$ Case T- 370/11 (2013).

${ }^{17} R v$ Secretary of State for the Environment, ex p Friends of the Earth [1994] 2 CMLR 760. On appeal, [1996] 1 CMLR 117.

18 [72]-[74]. The High Court rejected this claim, with Schiemann J (wrongly) suggesting that a claimant must show damage to enjoy EU law rights under the Directive [74]. The Court of Appeal (CA) ruled that the Directive did not oblige use of one particular enforcement technique, let alone a private right of action for damages [34]. Although the CA employed the language of rights, this is in a very different sense to EU law rights, with which it did not really engage.

${ }^{19} R$ (ClientEarth) v Secretary of State for the Environment, Food and Rural Affairs [2015] UKSC 28.

${ }^{20}$ (2015). The CJEU in this case interpreted the substantive non-deterioration element of the Directive in a very strict, un-nuanced way, despite the question marks that many had placed on the ease of enforceability of its substantive 'good' status element. That said, the case does not involve any reference to rights.

${ }^{21}$ As Chalmers and Chaves (2012) note, the legislator has a key influence, in norm-setting, on the scope for and nature of judicial politics.

${ }^{22}$ Case C-118/94 Associazione Italiana per il WWF v Veneto [1996] ECR I-1223.

${ }^{23}$ [1999] 3 CMLR 180.

${ }^{24}$ Decision 2005/370/EC on the conclusion of the Aarhus Convention; Regulation 1367/2006 on the application of the Aarhus Convention to Community institutions and bodies; Directive 2003/4/EC on public access to environmental information; Directive 2003/35/EC providing for public participation in respect of the drawing up of certain plans and programmes relating to the environment.

${ }^{25}$ Case C- 28/09 [2011] ECR I-13525.

${ }^{26}$ Case C-260/11 (2013). The procedural fundamental right mentioned (regarding a challenge to UK judicial review costs rules) was the right to an effective remedy under art 47 of the Charter.

${ }^{27}$ Case 25/62 [1963] ECR 95.

${ }^{28}$ Case C-293/97 [1999] ECR I-2603.

\section{Acknowledgements}

I am grateful to the anonymous reviewers for their helpful comments and also to Robert Kagan and those present at IPSA Montreal 2014 and CES Paris 2015 where earlier versions of this paper were delivered.

\section{Replication materials}

Supporting data and materials for this article can be accessed on the Taylor \& Francis website, doi:

\section{Disclosure statement}

No potential conflict of interest was reported by the author.

\section{Notes on contributor}

Chris Hilson is a professor of law at the University of Reading. His recent research interests include legal mobilisation, ecological citizenship, fracking, and climate change litigation. Address for correspondence: School of Law, Foxhill House, University of Reading, Reading RG6 7BA, UK.

\section{References}

Andersen, E.A. (2005) Out of the Closets and Into the Courts: Legal Opportunity Structure and Gay Rights Litigation, Ann Arbor: University of Michigan Press.

Bogojević, S. (2017, forthcoming) 'EU human rights law and environmental protection: the beginning of a beautiful friendship?', in S. Douglas-Scott and N. Hatzis (eds), Research Handbook on EU Law and Human Rights, Cheltenham: Edward Elgar.

Chalmers, D. and Chaves, M. (2012) 'The reference points of EU judicial politics', Journal of European Public Policy 19(1): 25-42. 
ClientEarth (2013) 'Supreme court calls on Europe to fast-track UK air pollution case', 17 July, available at http://www.clientearth.org/201307172236/news/press-releases/supreme-court-calls-oneurope-to-fast-track-uk-air-pollution-case-2236 (accessed 6 May 2016).

ClientEarth (2014) 'Illegal traffic pollution, the Queen and ClientEarth', 24 February, available at http://www.clientearth.org/201402242456/news/latest-news/illegal-traffic-pollution-the-queen-andclientearth-2456 (accessed 6 May 2016).

de Sadeleer, N. (2014) EU Environmental Law and the Internal Market, Oxford: OUP.

Epp, C.R. (1998) The Rights Revolution: Lawyers, Activists, and Supreme Courts in Comparative Perspective, Chicago: University of Chicago Press.

Ewick, P. and Silbey, S. (1998) The Common Place of Law: Stories From Everyday Life, Chicago: University of Chicago Press.

Friends of the Earth (1994) 'Friends of the Earth challenges Government in test case over pesticides in drinking water', 23 March.

Hilson, C. (1997) 'Community rights in environmental law: rhetoric or reality?', in J. Holder (ed.), The Impact of EC Environmental Law in the United Kingdom, Chichester: John Wiley \& Sons, pp. 51-68.

Hilson, C. and Downes, T. (1999) 'Making sense of rights: Community rights in E.C. Law', European Law Review 24: 121-138.

Hilson, C. (2002) 'New social movements: the role of legal opportunity', Journal of European Public Policy 9(2): 238-255.

Hilson, C. (2009) 'Risk and the European Convention on Human Rights: towards a new approach', Cambridge Yearbook of European Legal Studies 11: 353-375.

Hohfeld, W. (1919) Fundamental Legal Conceptions as Applied in Judicial Reasoning, New Haven: Yale University Press.

Howarth, W. (2009) 'Aspirations and realities under the Water Framework Directive:

proceduralisation, participation and practicalities', Journal of Environmental Law 21(3): 391-417.

Kagan, R. (1997) 'Should Europe Worry About Adversarial Legalism?', Oxford Journal of Legal Studies 17(2) 165-183.

Kagan, R. (2003) Adversarial Legalism: The American Way of Law, Cambridge, MA: Harvard University Press.

Kelemen, R.D. (2006) 'Suing for Europe: adversarial legalism and European governance’, Comparative Political Studies 39(1): 101-127.

Kelemen, R.D. (2011) Eurolegalism: The Transformation of Law and Regulation in the European Union, Cambridge, MA: Harvard University Press.

Lee, M. (2005) EU Environmental Law: Challenges, Change and Decision-Making, Oxford: Hart Publishing. 
Pedriana, N. (2006) 'From protective to equal treatment: legal framing processes and transformation of the women's movement in the 1960s', American Journal of Sociology 111(6): 1718-1761.

Prechal, S. and Hancher, L. (2002) 'Individual environmental rights: conceptual pollution in EU environmental law', Yearbook of European Environmental Law 2: 89-115.

Scott, J. (2000) 'Flexibility, "proceduralization", and environmental governance in the EU', in G. de Búrca and J. Scott (eds), Constitutional Change in the EU: From Uniformity to Flexibility, Oxford: Hart Publishing, pp. 259-280.

Stupples, L. (1993) The Times, July 27.

Vanhala, L. (2011) Making Rights a Reality? Disability Rights Activists and Legal Mobilization, Cambridge: Cambridge University Press.

Vanhala, L. (2012) 'Legal opportunity structures and the paradox of legal mobilization by the environmental movement in the UK', Law \& Society Review 46(3): 523-556. 